\title{
Bank vulnerability and avulsion modeling of the Bhagirathi-Hugli river between Ajay and Jalangi confluences in lower Ganga Plain, India
}

\author{
Raghunath Pal $^{1} \cdot$ Sumantra Sarathi Biswas ${ }^{1} \cdot$ Malay Kumar Pramanik ${ }^{2}$. \\ Biswajit Mondal ${ }^{1}$
}

Received: 23 March 2016/Accepted: 26 March 2016/Published online: 2 April 2016

(c) Springer International Publishing Switzerland 2016

\begin{abstract}
The emergence of the study of fluvial dynamics of the alluvial monsoon rivers especially in India is being enriched through the application of remote sensing and GIS techniques. To study fluvial dynamics over time, channel avulsion no doubt is one of the most considerable phenomena. The study section $(\sim 75 \mathrm{~km})$ in between the two confluences of the Bhagirathi River i.e., Ajay (Katwa) and Jalangi River (Nabadwip) confluence in Lower Ganga Plain of West Bengal is highly oscillatory in nature. Several satellite images and toposheets of different time periods $(1955,1973,1990$ and 2011) have been used in order to analyse the avulsive nature in this section of the river. These fluvial features (cut offs, ox-bow lakes, point bars etc.) form as a result of channel avulsion and have been identified with the help of Landsat satellite images. The decadal differences in sinuosity ratio in different parts of the studied section, channel migration rate and avulsion model explain the dynamic nature and crucial portions of high bank erosion rate of the channel in the mentioned time period. For both the reaches (R1 and R2), meander loop cut offs are dominant rather than lateral avulsion in the context of aggregate channel migration that also reflects the instability and erosional vulnerability at different meander bends.
\end{abstract}

Raghunath Pal

raghunath.geo17@gmail.com

1 Centre for the Study of Regional Development, Jawaharlal Nehru University, New Delhi 110067, India

2 Centre for International Politics, Organization and Disarmament, Jawaharlal Nehru University, New Delhi 110067, India
Keywords Avulsion modeling - Bank vulnerability · Satellite images · Floodplain - Anthropogenic influences

\section{Introduction}

Channel avulsion is a gradual process and the sudden abandonment of parts or meander belts of a river or the shifting of a channel to a new course of low elevation zone of the floodplain. Basically two types of avulsion are significant: lateral channel shifting and meander cut off (Allen 1965; Jones and Schumm 1999; Slingerland and Smith 2004). Alluvial channel flow is extremely controlled by continuous subsidence and alluvial facies development in the lower and middle course. The channel bank movement largely depends on bank composition and stream power which help to identify whether a channel is avulsed or not (Anderson et al. 1996; Keen-Zebert et al. 2013). Along with the mentioned factors, coexisting stratigraphic sequences to the channel are very useful evidence to analyse avulsive nature of the channel and new floodplain construction mechanism (Sinha 1996; Sinha and Ghosh 2012). Apart from this, there are many leaving landforms and exhumed features which develop during the transformation of a channel portion to a new floodplain or vice versa. Cutoffs, ox-bows, transitional point bars, meander scars etc. are few examples of such transformations. Although channel flow dynamics and planform morphology depend not only upon neo-tectonic activity or recent geomorphic events (lateral and vertical accretion) but long duration overwhelming condition, cyclonic burst, dam and barrage control on water release and rail lines, roads and bridges etc. also have a significant role (Gregory 2006; Schumm 2007; Benvenuti et al. 2008)). The study reach is a section of the Bhagirathi-Hugli River, a distributary of 
the Ganga River, dominated by monsoonal seasonality (Fig. 1). The river ( $\sim 75 \mathrm{~km})$ in between two confluences of the Bhagirathi River i.e., Ajay (Katwa) and Jalangi River (Nabadwip) confluence in Lower Ganga Plain of West Bengal has been taken as the study reach (Fig. 1). The studied section is identified as one of the most dynamic reaches of Lower Ganga Plain (Rudra 2008). The floodplain of the study area is the portions of the Ganga delta on the left bank and Rarh plain on the right. It means the river trough has dual impact in geomorphic perspective, one is new alluvium deposit and other is the old alluvium transfer from Chotanagpur plateau (north-east extension of Indian craton) respectively (Bagchi 1944; Basu 1964; Singh 1971, 2004; Rudra 2008). It is an area influenced by superimposed climatic condition i.e., a tropical fusty climatic signature on monsoon environment which influences the discharge variability of the rivers throughout years (Sanyal and $\mathrm{Lu} 2005$ ). Furthermore, it is a neo-tectonic zone largely dominated by Holocene geology (Singh 1971; Benvenuti et al. 2008). On the evolution of the Bhagirathi river there is an argumentative view that it was the prime channel of the Ganga and during Mid-Holocene earthquake in this region the channel shifted towards modern Padma whereas Bhagirathi remained as the secondary channel (Rudra
1999; Tandon et al. 2008; Rudra 2010; Gupta et al. 2014). In the mid-16th century, a major earthquake occurred which further helped to change the tectonic setting of underlying plates and due to the eastward tilting of the plates, the river shifted from Bhagirathi to the present Padma (Gupta et al. 2014). There is an important evidence that an ancient port (Tamralipta) and many pilgrimages had developed along the Bhagirathi river banks and that there hardly exists such type of evidence for the Padma. From this point of view, it can be said that the main channel was the Bhagirathi-Hugli River (Majumdar 1942; Rudra 1999). But the trend of flow indicates that the Padma trough is normal to flow towards the east direction as the main channel rather flow in the south direction (Rudra 2008).

Anthropogenic factors (dam and barrage, embankments, rail line and road, bridge construction and changing land use practices etc.) have influenced the river morphology and have been focussing in the past few decades (Williams and Wolman 1984; Kondolf 1997; Knighton 1998; Kondolf et al. 2002; Gregory 2006; Schumm 2007; Xu et al. 2007; Kiss et al. 2008; Kiss and Blanka 2012; Vandenberghe et al. 2012). In 1975, the feeder canal and the Farakka barrage were constructed at Farakka to rejuvenate the Bhagirathi-Hugli water flow which has considerable

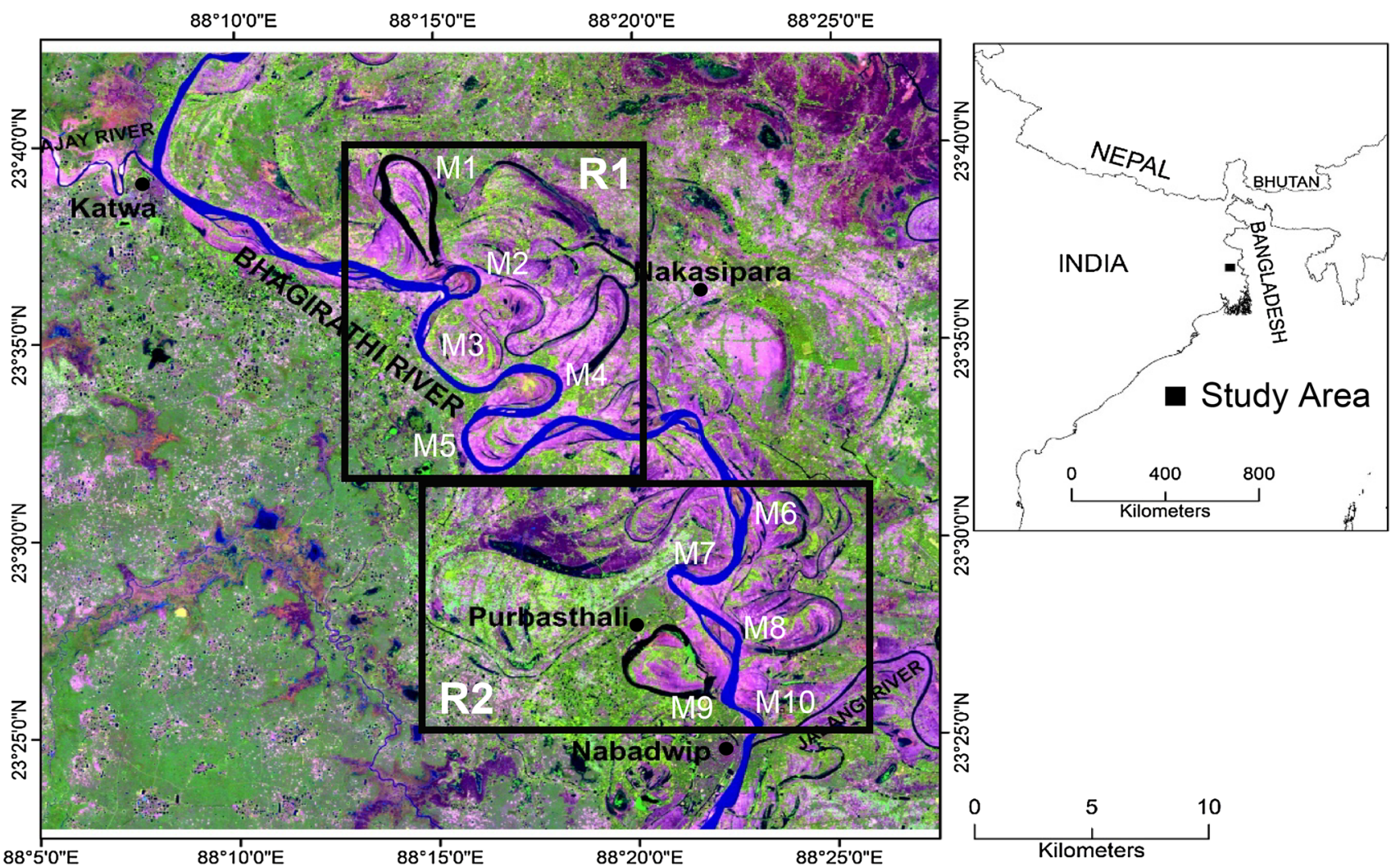

Fig. 1 Temporal changes of the meander amplitude of two reaches from 1955 to 2011. M1 and M9 has experienced with reduction of amplitude for the cut off development 
impacts on the river hydraulics (Basu et al. 1966; Basu and Sen 1997). Moreover, large dams and barrage constructions on the right hand tributaries of the Bhagirathi-Hugli like the Panchet dam, Tenughat dam and Durgapur barrage on Damodar, Kangshabati dam on Kangshabati, Massanjore dam and Tilpara barrage on Mayurakshi have affected the tributaries as well as the main channel morphology. Finally, the construction of roads, rail lines and buildings along the river banks are changing the surface structure of the floodplain constantly (Rudra 2008). The present research is mainly concerned with the channel avulsion (meander loops migration and cut offs development) across the time span of 56 years and present channel planform along with the erosional vulnerability of the active floodplain due to avulsion of the Bhagirathi River in lower Gangetic plain.

\section{Regional settings}

The vast alluvial plain of the Bhagirathi delta can be demarcated in between the Rarh plain and Mathabhanga River (distributary of the Padma and tributary of the Bhagirathi) in the western and the eastern side of the Bhagirathi River respectively (Singh 1971). The eastern tributaries have shifted their courses several times due to meander migration and avulsion whereas the western tributaries are relatively less dynamic in the context of shifting (Basu and Sen 1997). The evolution of the Bhagirathi delta plain is the result of the simultaneous mechanisms of neo-tectonic activity, high discharge fluctuation, subsidence of land and deposition of sediment load and contuninuing readjustment of the cratonic old mass and new sedimentary facies (Bagchi 1944; Wadia 1975; Krishnan 1982; Mukherjee et al. 2009; Rudra 2014). The study reach surface morphology is composed of quarternary fluvial processes, underlying uneven geologic basement, long term climatic transformation and superimposition. The present conditions of the south bengal river system are characterised by large amount of water release from the Farakka barrage to the Padma, gradual reduction in the stream power of Ganga's ditributaries (i.e., Bhairab, Jalangi, Mathabhanga and Bhagirathi) (Basu and Sen, 1997; Sinha and Ghosh 2012), southward hanging of the Damodar's distributaries and palaeo existence of its eastward original path etc. (Basu 1964; Rudra 2014). The study reach is located $\sim 145 \mathrm{~km}$ south of Farakka and $\sim 280 \mathrm{~km}$ north of the Bay of Bengal towards. Probably the Bhagirathi-Jalangi confluence is the end zone of tidal influence (Rudra 2008), that means the reach has no considearble influence of the tides. In the location map (Fig. 1), the right bank floodplain of the reach 2 (R2) indicates a palaeochannel existence that was formed prior to the Damodar channel and has shifted in the south direction during 18th century. It has thus created an inticate pattern of channel flow system (Singh et al. 1998). Moreover, construction of dams and barrages in the upper reach of the Damodar river are resposible for the modification of the lower reach distributaries which are about to defunct condition at present (Basu and Sen 1997; Rudra 2008).

\section{Materials and methods}

The time scale for the study is 56 years, meaning that satellite images and toposheets have been used for highlighting the temporal changes of the river course. In the present study, satellite remote sensing data of Landsat 5 MSS (spatial resolution $80 \mathrm{~m}$ ), TM and Landsat 7 ETM+ (spatial resolution $30 \mathrm{~m}$ ) have been collected from USGS Earth Explorer website (http://earthexplorer.usgs.gov). To extend the investigation time period of channel avulsion, the topographical sheets (Scale 1:250000) have also been used and collected from the University of Texas Library (http://www.lib.utexas.edu/maps) as satellite images are not available before 1972 (Table 1). For the analysis collected toposheets (NF 45-3, NG 45-15) were georeferenced using several ground control points considering Everest 1956 projection system. In order to remove the resolution error MSS images have been resampled to $30 \mathrm{~m}$ (because $\mathrm{TM}$ and $\mathrm{ETM}+$ images have $30 \mathrm{~m}$ resolution). The ATSER digital elevation model data have been used for the generation of cross profiles across the river and its floodplain to get overall topography of the floodplain. For ASTER DEM data authentication spot height data have been plotted against the ASTER DEM heights and the resulted value $\left(R^{2}=0.945\right)$ indicates the data is useful. Voids in the ASTER DEM data have been removed by inserting proxy values in the images using raster calculator.

For better understanding the study section has been seperated into two different reaches considering the zones of high avulsion rate. The reaches $\mathrm{R} 1$ and $\mathrm{R} 2$ contain two meander cut offs and these are most dynamic nature in the study area (Fig. 1). Remote sensing data from Landsat 7 $\mathrm{ETM}+$ (spatial resolution $30 \mathrm{~m}$ ) have been used to show the meander cut offs for its recent availability (2011) and better quality. To understand the channel length shortening due to the cut offs in both the reaches has been calculated from the images (ETM 2011) considering the cut off axis and the radius of curvature. Channel migration scenario has been monitored, taking into consideration a data spanning over four different period (1955, 1973, 1990 and 2011). Further, several meander parameters such as meander wavelength, meander amplitude, radius of curvature and channel width for different cross sections etc. have been taken for the monitoring of aggregate meander migration 
Table 1 Data used for the study and analysis

\begin{tabular}{llll}
\hline Data type & Details & Year/data & Source \\
\hline Satellite remote sensing data & & & \\
Landsat 5-MSS & 80 m resolution & 1973 & USGS Earth Explorer \\
Landsat 5-TM & $30 \mathrm{~m}$ resolution & 1990 & \\
Landsat 5-ETM+ & $30 \mathrm{~m}$ resolution & 2011 & \\
DEM data & $30 \mathrm{~m}$ resolution & 2011 & USGS Earth Explorer \\
ASTER DEM & & & US Army Survey Maps \\
Maps & Scale 1:250000 & 1955 & \\
Topographical maps & & &
\end{tabular}

and migration rate in the two reaches. Meander migration rate and aggregate migration have been calculated considering the channel shifting along all meander axes of the reaches within the studied period (Gupta et al. 2014; O'Conno et al. 2003). Here, sinuosity index has also been measured for both the reaches in order to reflect the changes in the meander over the studied period. It has been measured by dividing the mid-channel length for the same reach or the mid-channel length of the widest channel $\left(L_{\text {emax }}\right)$ with the overall length of the channel-belt reach measured along a straight line $\left(L_{R}\right)$ (Friend and Sinha 1993). In order to analyse the morphological translocation and the evolution of the channel across the studied period, an individual collage of four cells of 1955, 1973, 1990 and 2011 have been prepared for the reaches.

An avulsion model has been proposed to prepare bank vulnerability zonation map considering total erosion and the rate of erosion of the each meander axis across the study reach. Buffer ( $2 \mathrm{~km}$ wide from the channel) and ordinary kriging technique have been used to highlight the migration rate zones and the highly erodable channel bank areas. The equations of kriging method can be derived in the following way (Chang 2010):

$z_{0}=\sum_{i=1}^{s} z_{x} W_{x}$

where, $z_{0}$ is the estimated value of the channel migration, $z_{x}$ is the known value at each meander axis $(\mathrm{x}), W_{x}$ is the weight associated with the each meander axis ( $\mathrm{x})$, and $\mathrm{s}$ is the number of sample axes used in modeling.

To estimate a point $(\mathrm{x})$ three known points are important and for that following equations are needed:

$W_{1} \gamma\left(h_{11}\right)+W_{2} \gamma\left(h_{12}\right)+W_{3} \gamma\left(h_{13}\right)+\partial=\gamma\left(h_{10}\right)$

$W_{1} \gamma\left(h_{21}\right)+W_{2} \gamma\left(h_{22}\right)+W_{3} \gamma\left(h_{23}\right)+\partial=\gamma\left(h_{20}\right)$

$W_{1} \gamma\left(h_{31}\right)+W_{2} \gamma\left(h_{32}\right)+W_{3} \gamma\left(h_{33}\right)+\partial=\gamma\left(h_{30}\right)$

$W_{1}+W_{2}+W_{3}+0=1.0$

where, $\gamma\left(h_{i j}\right)$ is the semivariance between two known axes point $\mathrm{i}$ and $\mathrm{j}, \gamma\left(h_{i 0}\right)$ is the semivariance between ith axis point and the point to be estimated of same axis and $\partial$ is a Lagrange multiplier (minimum possible estimated error). The Eq. (1) can be used to estimate $z_{0}$ after solving the Eq. (2), (3) and (4).

$z_{0}=z_{1} W_{1}+z_{2} W_{2}+z_{3} W_{3}$

The variance estimation $\left(s^{2}\right)$ can also be calculated in kriging method. The equation for this calculation is

$s^{2}=W_{1} \gamma\left(h_{10}\right)+W_{2} \gamma\left(h_{20}\right)+W_{3} \gamma\left(h_{30}\right)+\partial$

\section{Surface scenario of the study reaches}

The studied section of the lower gangetic plain is under the floodplain area of the Bahagirathi and new deposit of its western and eastern tributaries. The average elevation of the floodplain is below $20 \mathrm{~m}$ and it is $>20 \mathrm{~m}$ for the right bank and $<19 \mathrm{~m}$ for the left. The Bhagirathi river flows towards the south-east direction after Ajay-Bhagirathi confluence, but after that it flows to the south up to the Jalangi-Bhagirahi confluence. The cross sections (P1, P2, P3 and P4) across the Bhagirathi River and its floodplain reflects the general trend of slope from the west to the east of the floodplain (Fig. 2). Except the leeves that has the overall slope nearly same across the entire floodplain. The elevation of the banks or the natural levees are higher than the floodplain and surface undulation of the floodplain is insignificant for all cross sections. The width of the active channel varies from $250-950 \mathrm{~m}$. The recent and past cut offs over the floodplain reflects the unevenness and depressions in the profiles.

\section{Results and discussion}

\section{Dynamicity of the Bhagirathi River in the reach 1}

The study of reach 1 (R1) exhibits a large meander cut off that occurred between 1990 and 2011. The development of meanders (1955-2011) is a significant geomorphic process 

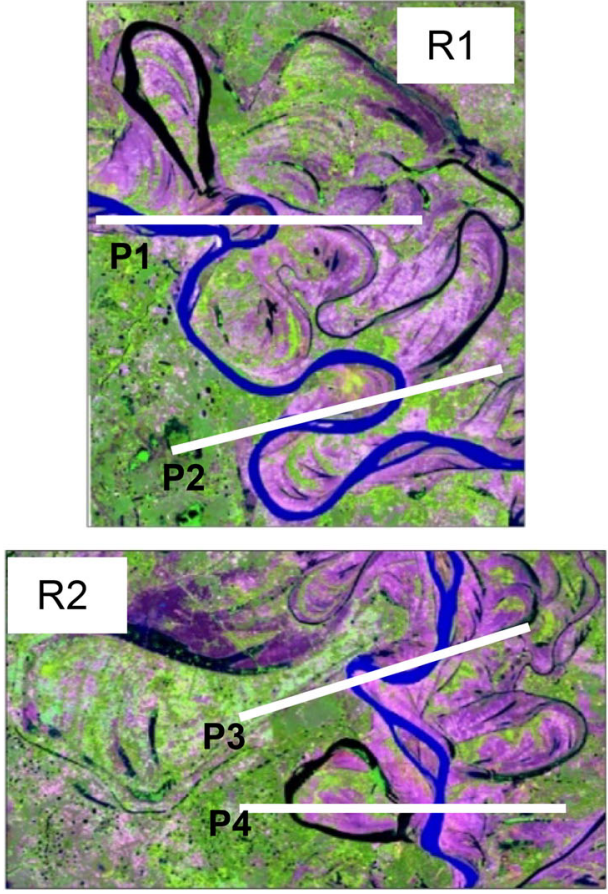

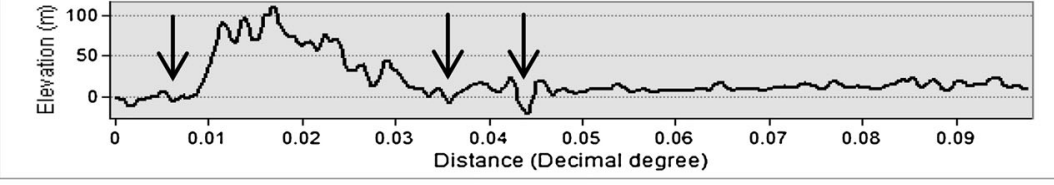

P1

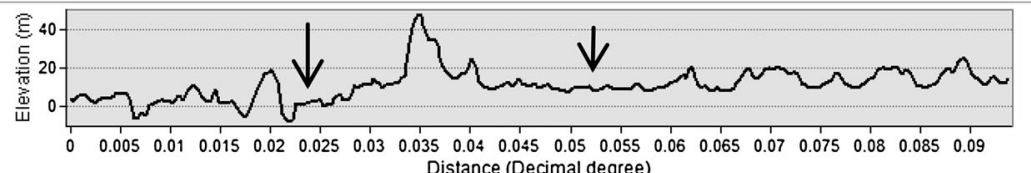

Distance (Decimal degree)

P2

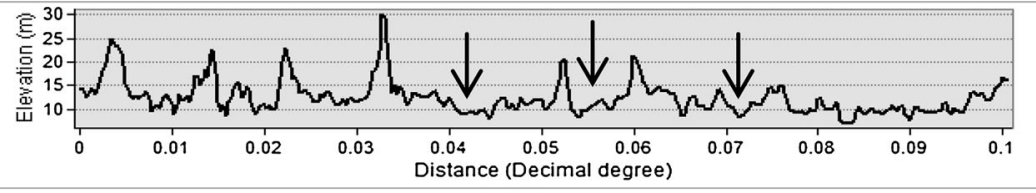

P3

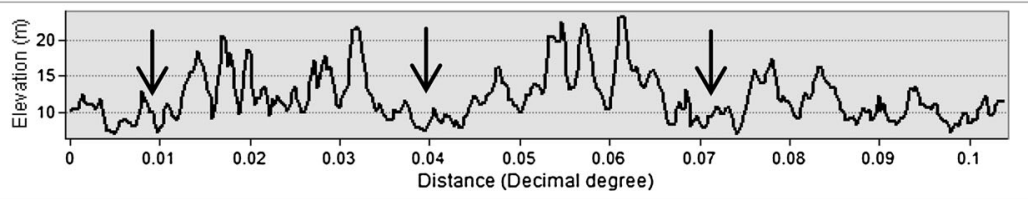

P4

Fig. 2 Location of the study area. R1 and R2 represents the reach 1 and reach 2 respectively which are most avulsive in the study section. M1 to M10 indicate the meander loops

in this reach (Fig. 3). From 1955-2011, the meander wavelength and amplitude have transformed resulting the conversion of the channel from tortuous to relatively straight channel and the meander loop conversion into cutoff. The increase of meander wavelength in 1973 and 1990 is associated with the east-west lateral migration in the floodplain. The general mechanism of meander bend growth can explain the meandering in the study reach that is the center of mass is shifted towards the concave bank and for that reason erosion becomes less prominent where the convex bank is started to deposit laterally towards the concave bank. Except the M1 meander loop, all the other meanders have faced gradual oscillation of meander amplitude during 1955-2011 (Fig. 3). In 2011, M1 meander faced a neck cut off in the main channel flow, which reduced the amplitude (from $8.63 \mathrm{~km}$ in $1990-3.89 \mathrm{~km}$ in 2011) and wavelength (from $12.71 \mathrm{~km}$ in 1990-6.06 km in 2011) of the channel. As a result of the reduction of the channel length $\left(2.31 \mathrm{~km}\right.$ and 41.25 m.year $\left.^{-1}\right)$ the flow distance also decreases which further forced the channel flow to become more active. Before the cutoff formation, the channel flowed through the meander bends. If the transformation of the meander loops is taken for reach 1 (R1), two channel flow location i.e., M2 and M4 are significant. In future, these reaches may face the formation of meander cutoff with the presence of cutoff lakes and the channel may flow in a straight way. In R1, with the development of meanders, the convex banks face meandering scrolls and point bars growth towards the concave bank of a meander loop. These are associated with significant depositional processes in the channel flow of the point bar surroundings. The sinuosity of the reach (R1) over the studied period shows that gradual increase in the meandering nature (increase of sinuosity value from 2.52 in 1955 to 2.84 in 1990) of the river from 1955 to 1990 and it is associated with the common increase of meander wavelength and amplitude (Fig. 3). But, in 2011, a drastic reduction in sinuosity (1.77) occurred due to the cutoff and detachment of the meander loop. In R1, several palaeo cutoffs and meander scrolls formed on the eastern side of the floodplain before the studied time period. The eastern side of the Bhagirathi River have most of the palaeo cutoffs and the reason is simple the new deltaic alluvial deposits are less consolidated in relation to the west floodplain high resistive deposits. Over a long period of time, three significant cutoffs have been noticed in this reach to the east bank floodplain. On the contrary, western side of the Bhagirathi River is hardly associated with any type of cutoff development. The above interpretation is some where contrasting with the argument that the Bhagirathi was the premier channel of the Ganga and was shifted towards the east (present Padma River) because the channel is shifted towards the right bank floodplain (analysis from the footprints of the palaeo-channels in the satellite 
Fig. 3 Cross-profiles across the studied reaches. P1, P2, P3, P4 represent the floodplain surface morphology. Arrows indicate the present channel position
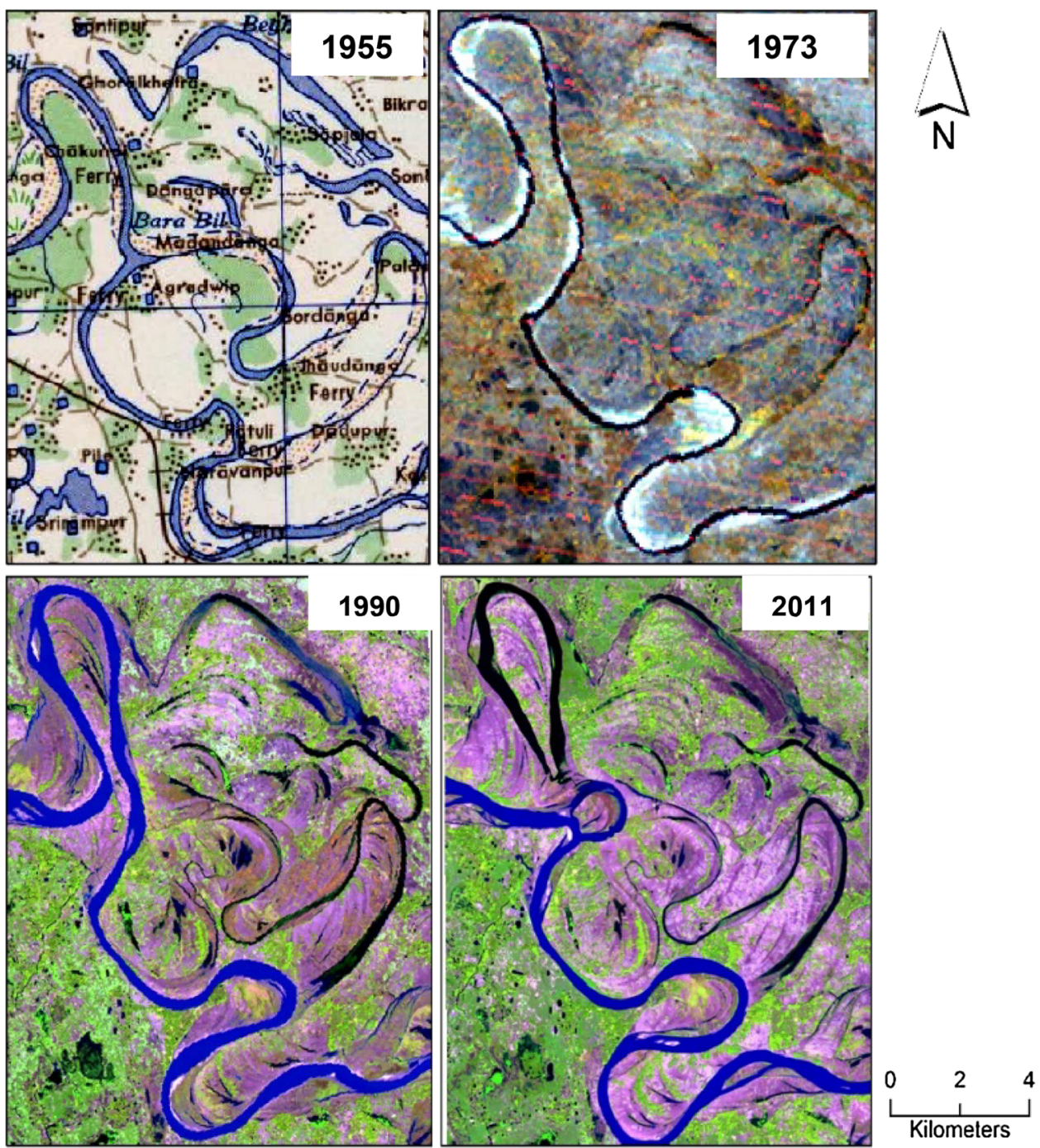

images). Although it is hardly possible to say that the Bhagirathi channel trough was not the actual trough of the Ganga river because our studied time period is 56 years only and the evidence of the palaeo channels in the satellite images are not of Mid-Holocene.

\section{Dynamicity of the Bhagirathi River in the reach 2}

In R2 the development of meanders (1955-2011) is also a significant geomorphic change in this reach. Meander wavelength and amplitude have changed over the studied period. Meander amplitude of the meanders has increased from 1955 to 1973 . But, in 1990, there was a significant decrease in the meander length for M5 and M8. This may be associted with the channel straightening due to the neck zone bank erosion of the meander loop (Fig. 4). In this reach, no cutoff formation has taken place in between 1973-1990. In 2011, the decrease of meander amplitude for M7 and M8 was a result of cutoff development. In the
$\mathrm{R} 2$ reach, the reduction of channel length is higher than in $\mathrm{R} 1$. This reach faces a reduction of $5.29 \mathrm{~km}(25 \%)$ of the channel length, while the reach 1 (R1) has faced a reduction of $2.32 \mathrm{~km}(7.32 \%)$ (Fig. 5) in the studied 56 years. As the cutoff has formed, the flow diverts to the new straight channel and the cutoff becomes as a water reservoir. With the development of meanders, the convex banks have formed numeros meandering scrolls (Fig. 6). The values of sinuosity index indicate a gradual increase in meander wavelength and amplitude (increase of sinuosity value from 1.80 in 1955 to 2.18 in 1990) that means the length of the channel has increased from 1955 to 1990 (Fig. 7). But, in 2011, the drastic reduction was observed due to the cuting off of the meander which reduced the Sinuosity value (1.42) of the reach. In this portion, cut off forming mechanism is observed in both the eastern and western sides of the Bhagirathi River. Both sides have experienced three cut offs before the studied time period (Fig. 1). 

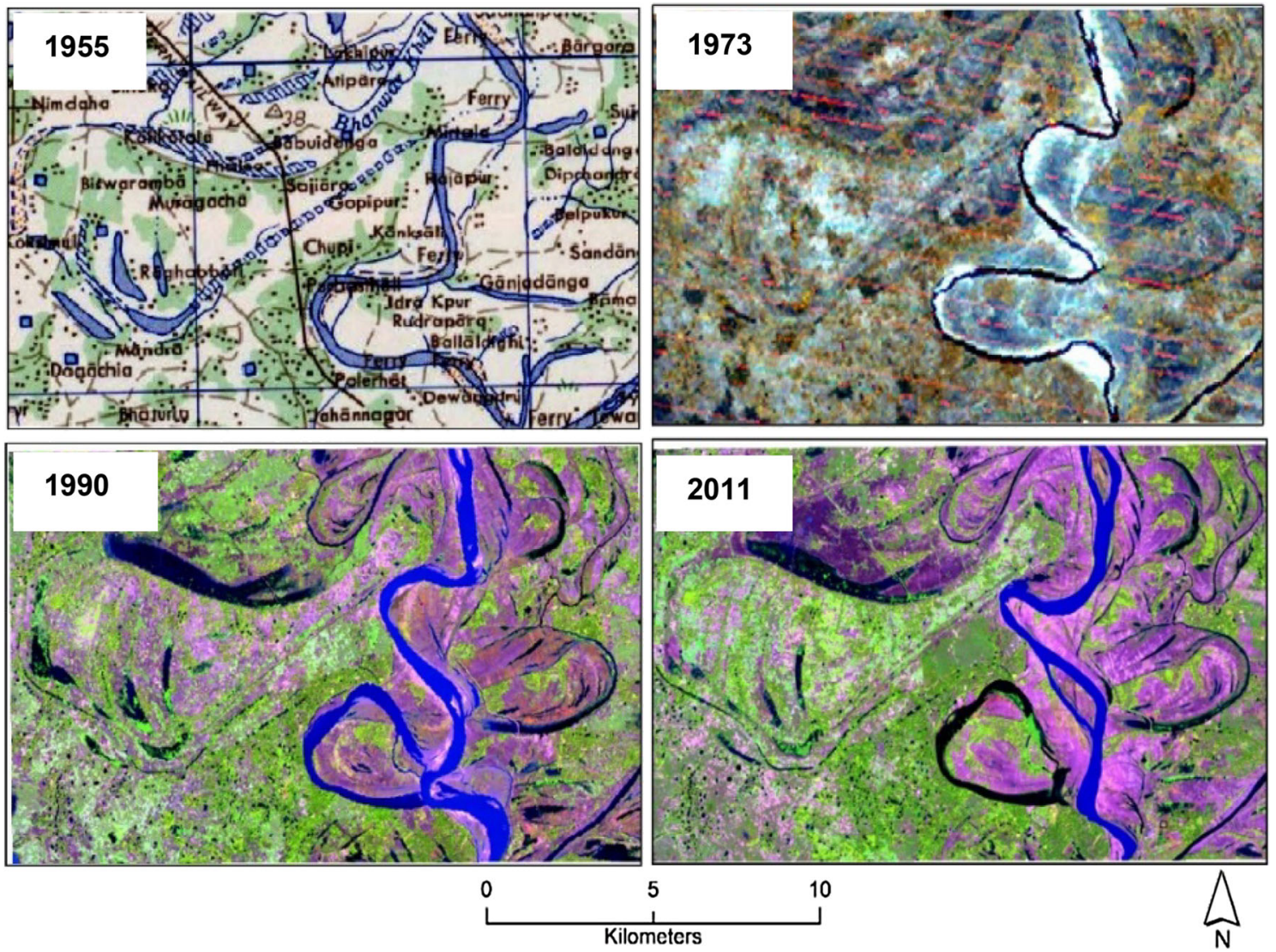

Fig. 4 Dynamicity of the river of the reaches and reach wise meander bends and cut off development from 1955-2011
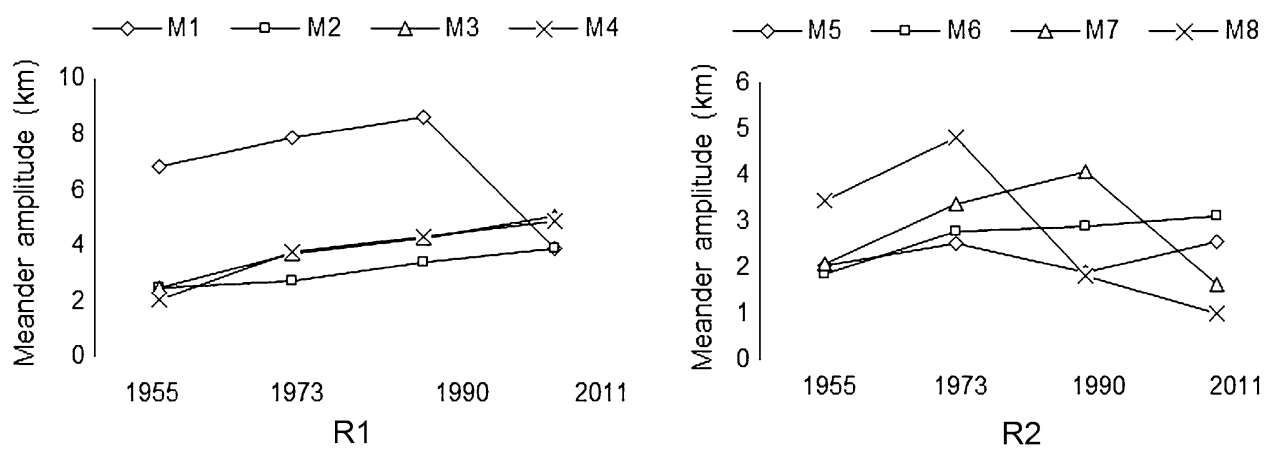

Fig. 5 Channel migration scenario in the Reach 2 from 1955 to 2011. Significant changes are from 1973 to 1990 and from 1990 to 2011 (cut off development in the penultimate meander loop)

\section{River bank vulnerability}

The spatial distribution of the rate of avulsion or channel migration is uneven. The graphics of bank vulnerability has been generated along the river channel of the studied section considering the time period of 1955-2011(Fig. 8). In this zonation map dark areas represent high bank erosion $(4.17 \mathrm{~km})$, while the lighter shaded areas represent less erosion $(0.27 \mathrm{~km})$. High erosion or channel migration is observed in reach 1 and 2 and is associated with the meander cutoffs. The confluence zones of the Ajay and Jalangi River are associated with negligable erosion or lack of avulsion. This indicates that the confluences are not much dynamic, probably because in recent time the Jalangi river has a constant flow through out the year except during the monsoon season. Whereas, the Ajay river remains dry except during the wet season. Channel migration in the studied section is high and the rate of migration for most of the meander axes is over $40 \pm 3.5$ month year ${ }^{-1}$. The average rate of channel migration of the study reach is 
Fig. 6 Changes of Sinuosity index (SI) over studied period (A). Reach wise reduction of channel length from 1955 to 2011. Sudden decrease of SI value and channel length in both reaches indicate cut off development

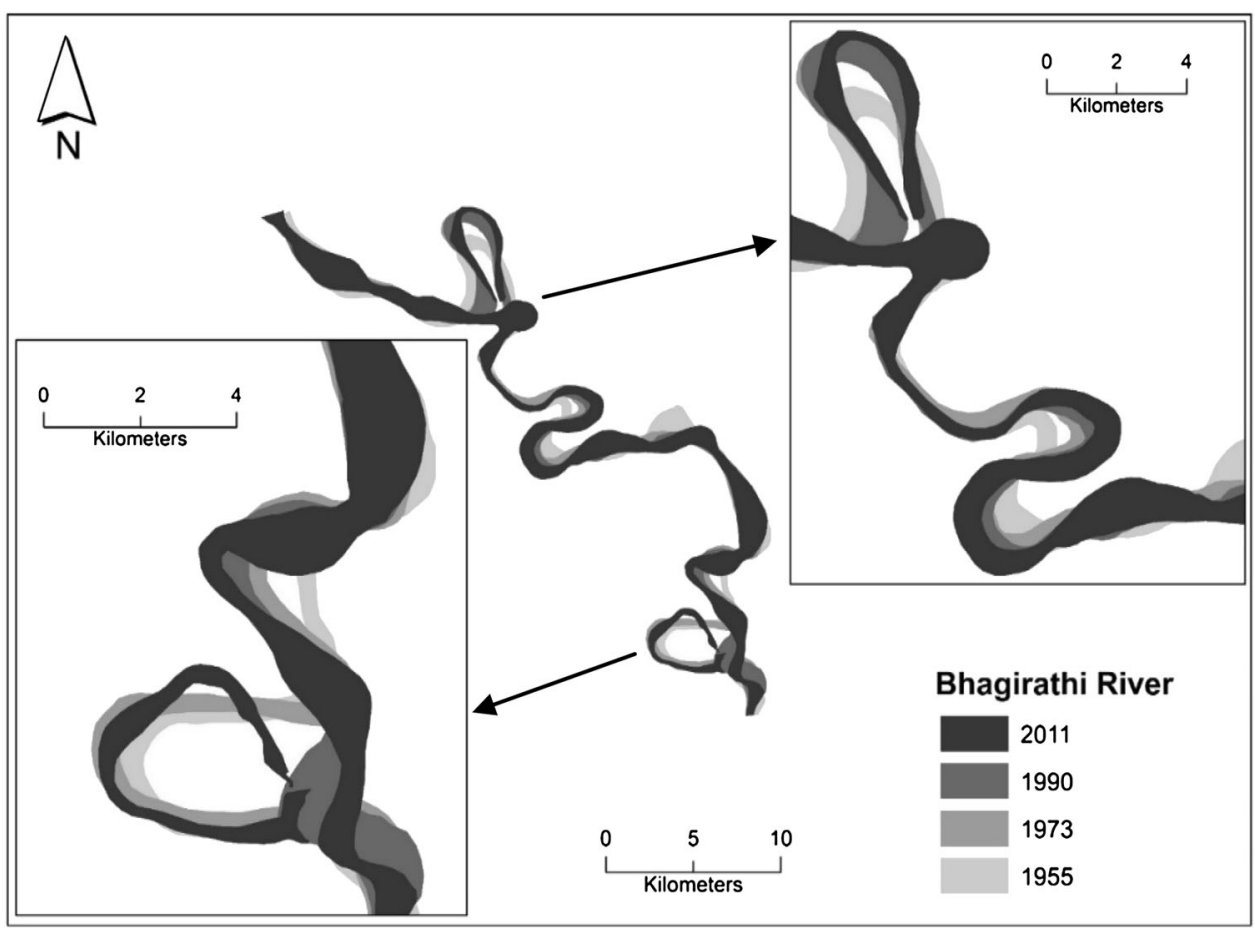

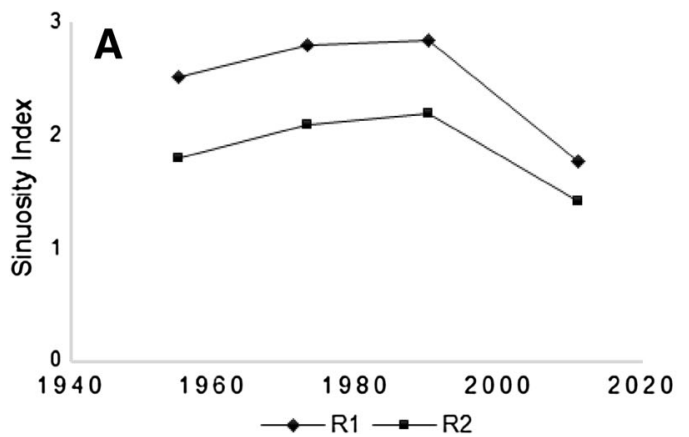

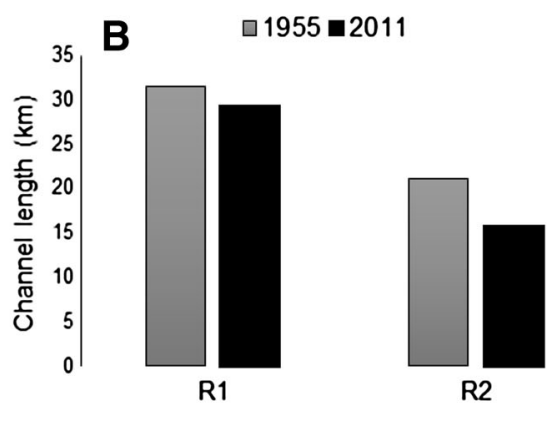

Fig. 7 Channel migration scenario in the Reach 1 from 1955 to 2011. Significant changes are from 1955 to 1973 and from 1990 to 2011 (cut off development in the very first meander loop)

$29.93 \pm 3.5$ month year ${ }^{-1}$. M1 and M9 meander axes have a high value of channel migration as both of these axes are associated with meander cutoffs and have migrated for more than $4 \mathrm{~km}$ during the entire studied period (Fig. 9). Because of the high rate of bank erosion and changing floodplain environment local habitats face many difficulties especially during floods. In the study reaches, from the analysis of LANDSAT satellite images, many palaeo cut offs have been identified. From the above discussion it may be stated that the Bhagirathi-Hugli channel has long time experienced planform evolution and lateral oscillation in zigzag style.

It can be pointed out that reach 1 and 2 are the most vulnerable portion in comparision to the other portions of the river in the context of bank erosion. The palaeochannels and the analysis of 56 years channel shifting indicate that the channel is highly erosive in the study reach. The reasons are probably in the study reach and its upper portion up to Saragachi, two confluences (Ajay and Mayurakhi) have influenced the discharge volume of the Bhagirathi river which increases kinetic energy to enforce the hydraulic dynamicity and channel oscillation. Secondly, the channel banks in the study area are free from embankments which make the channel continue its dynamicity. The upper portion of the Bhagirathi river (from Farakka to Saragachhi $\left(24.01^{\circ} \mathrm{N}, 88.15^{\circ} \mathrm{E}\right), \sim 130 \mathrm{~km}$ from Farakka in the south direction), the channel is less dynamic after the construction of Farakka barrage and feeder canal 


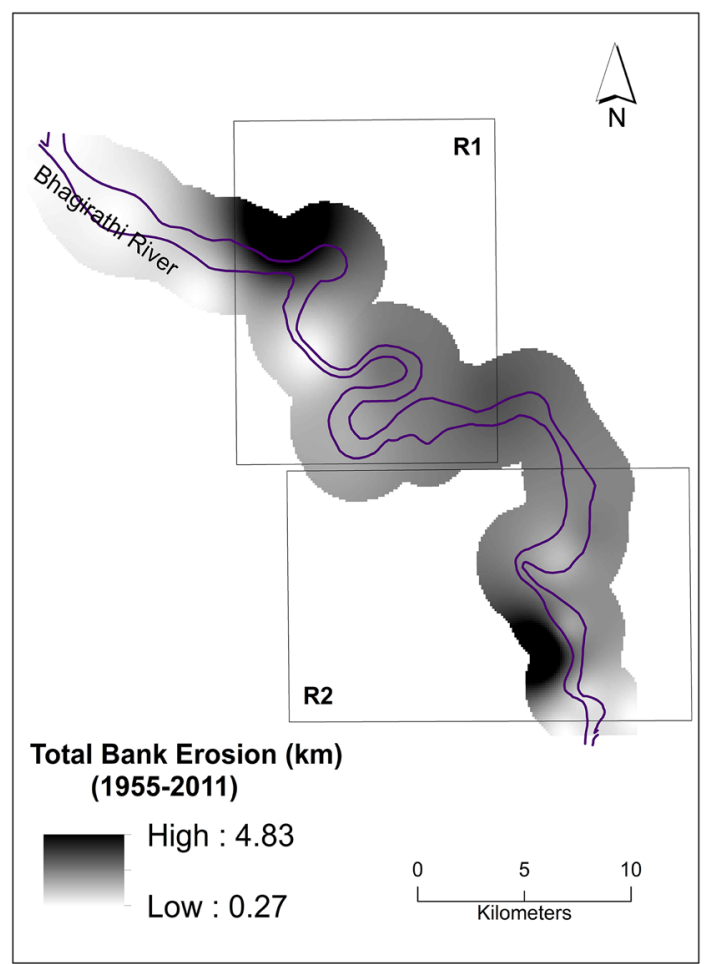

Fig. 8 Bank vulnerability zones (avulsion model) of the reach from 1955 to 2011 with help of kriging. Two cut off zone is associated with the higher degree of dynamics

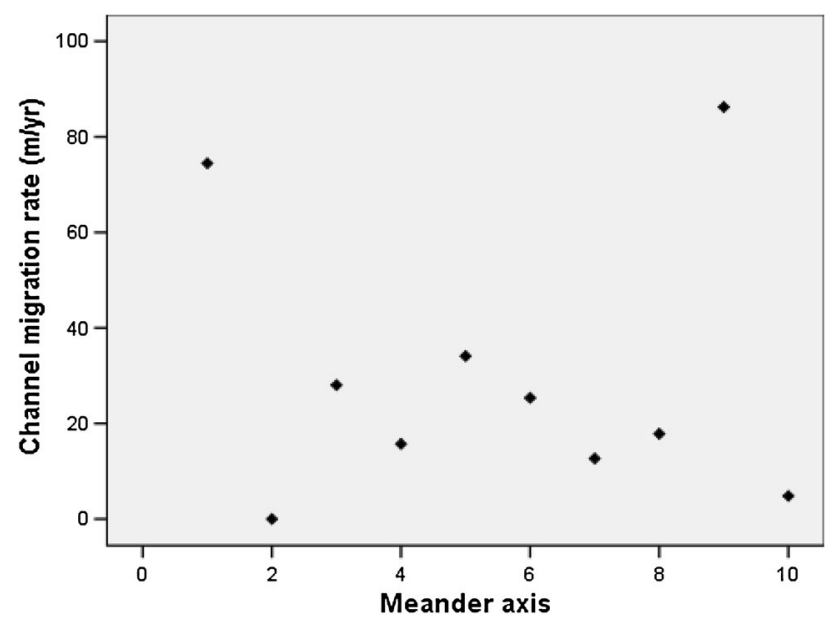

Fig. 9 Rate of channel migration and erosion based on meander axis from 1955 to 2011. First and penultimate meander axis has high migration rate for cut off development

(Basu and Sen 1997). It is because of the constant release of silt free water $\left(0.14 * 106 \mathrm{t}\right.$. year $\left.{ }^{-1}\right)$ from the barrage that helps less erosion and deposition in the channel and towards the banks. Further, except the Mayurakhi river there is no such type of tributaries to contribute enough discharge to the Bhagirathi which also helps the channel to be less dynamic. Moreover, the supply of water to the main channel occurs mainly during the wet season and the presence of a fault line, in the upper portion of the AjayBhagirathi confluence, has influenced the lack of high dynamicity (Singh et al. 1998). There is an influence of ebb and tide in the lower portion (from the Bhagirathi-Jalangi to river mouth) of the river which makes the channel less dynamic. The consequence of tidal influences is the entrance of tides to the channel which help to deposit a large amount of silt on the banks and the channel. The mechanism is the reduction of kinetic energy due to the convergence and diminishing of the river flow and the tides help to reduce the flow velocity and increase the silting processes. The embankment construction and urban growth along both the channel banks have forced the channel to mentain a static condition. As a result depth of the Bhagirathi river is decreasing day by day (Rudra 2008).

\section{Conclusion}

Avulsion of the Bhagirathi-Hugli River is spontaneous in nature that reflects its morphological activeness in the deltaic plain constituent. The backwater effects in the river and periodic sedimentation (Gupta et al. 2014) along with a constant supply of water discharge through the feeder canal from the Farakka barrage favour its activeness. It seems that lateral accretion is a dominant process of meandering and continuous reconstruction of the active floodplain of the river. The evidence for lateral accretion have been identified from toposheets (1955) and Landsat images (1973, 1990 and 2011) and these are: meander scars, cut offs, ox-bows and palaeo channels etc. On the other hand, vertical accretion is less effective because the incidence of floodplain inundation is less frequent in the study reach especially after the Farakka barrage construction. In both the reaches (R1 and R2), meander loop cut offs are more significant rather than lateral erosion in the context of aggregate channel migration. The cut offs of the reaches have developed on the active floodplain area where agricultural practices are predominant and largely affected by channel and floodplain inter-transformation. In recent time, human habitat dynamics and vigorous bank erosion have become important issues. The development of the meander loops and migration of the channel bank compel to shift human habitats. Sometimes, high floods play a significant role to affect the channel bank stability and floodplain environment. There is a long term and constant influence of seasonality and yearly effect of cyclonic burst on the discharge variability in the study reach which could not be analysed in this study due to the unavailability of sufficient data. Moreover, sedimentological readjustments due to aggradation and degradation of the banks, stratigraphic 
sequences of channel bars and deltaic neo-tectonic evolution etc. are probably some of the underlying factors which are the causes of the channel bank erosion and instability in the Holocene period. Hence, to understand the channel bank erosion history and its impact on human habitat and river environment more extensively, a multidisciplinary approach may be useful.

Acknowledgements The authors are highly thankful to their friend Ms. Tiyali Bose, Research Scholar, Indian Institute of Technology, Kharagpur (IITK), for her help in proof reading.

\section{References}

Allen JL (1965) A review of the origin and characteristics of recent alluvial sediments. Sedimentology 5:89-191

Anderson MG, Walling DE, Bates PD (1996) Floodplain processes. Wiley, Chichester

Bagchi K (1944) The Ganges Delta. Calcutta University Press, Kolkata

Basu SR (1964) A study of the Bhagirathi River. The Observer. Students Geographical Association, University of Calcutta, Kolkata, p 10

Basu SR, Sen A (1997) A study on the recent changes (1978-1992) in the morphology of River Hooghly. Indian J Geomorphol 2(1):39-49

Basu SR, Sen A, Ghosh A (1966) A study on the morphology and hydrological changes of the Hugli River during 1973-1993. Natl Geogr XXXI $(1,2): 57-58$

Benvenuti M, Bonini M, Moratti G, Ricci M, Tanini C (2008) Tectonic and climatic controls on historical landscape modifications: the avulsion of the lower Cecina River (Tuscany, central Italy). Geomorphology 100:269-284

Chang K (2010) Introduction to geographic information systems. Tata McGraw Hill Education Private Limited, New Delhi

Friend PF, Sinha R (1993) Braiding and meandering parameters. In: Best JL, Bristow CS (eds) Braided Rivers. Geological Society of London Special Publication, London, pp 105-111

Gregory KJ (2006) The human role in changing river channels. Geomorphology 79:172-191

Gupta N, Kleinhans MG, Addink EA, Atkinson PM, Carling PA (2014) One-dimensional modeling of a recent Ganga avulsion: assessing the potential effect of tectonic subsidence on a large river. Geomorphology 213:24-37

Jones LS, Schumm SA (1999) Causes of avulsion: an overview. In: Smith ND, Rogers J (eds) Fluvial sedimentology VI. Blackwell, Oxford, pp 171-178

Keen-Zebert A, Tooth S, Rodnight H, Duller GT, Roberts HM, Grenfell M (2013) Late quaternary floodplain reworking and the preservation of alluvial sedimentary archives in unconfined and confined river valleys in the eastern interior of South Africa. Geomorphology 185:54-66

Kiss T, Blanka V (2012) River channel response to climate and human induced hydrological changes: case study on the meandering Hernád River, Hungary. Geomorphology 175-176:115-125

Kiss T, Fiala K, Sipos G (2008) Alterations of channel parameters in response to river regulation works since 1840 on the Lower Tisza River (Hungary). Geomorphology 98(1-2):96-110
Knighton D (1998) Fluvial form and processes-a new perspective. Arnold, London

Kondolf GM (1997) Hungry water: effects of dams and gravel mining on river channels. Environ Manag 21(4):533-551

Kondolf GM, Piégay H, Landon N (2002) Channel response to increased and decreased bedload supply from land use change: contrasts between two catchments. Geomorphology 45:35-51

Krishnan MS (1982) Geology of India and Burma, 6th edn. CBS Publishers and distributors Pvt. Ltd, New Delhi

Majumdar SC (1942) Rivers of Bengal Delta. Calcutta University, Kolkata

Mukherjee A, Fryar AE, Thomas WA (2009) Geologic, geomorphic and hydrologic framework and evolution of the Bengal basin, India and Bangladesh. J Asian Earth Sci 34(3):227-244

O'Conno JE, Jones MA, Haluska TL (2003) Flood plain and channel dynamics of the Quinault and Queets Rivers, Washington, USA. Geomorphology 51:31-59

Rudra K (1999) The hypothesis of easterly flight of the Ganga water: fact or fiction? Indian J Geogr Environ 4:52-56

Rudra K (2008) Banglar Nadikatha (in Bengali). Sahitya Samsad, Kolkata

Rudra K (2010) Dynamics of the Ganga in West Bengal (1764-2007): implications for science-policy interaction. Quatern Int 227(2):161-169

Rudra K (2014) Changing river courses in the western part of the Ganga-Brahmaputra delta. Geomorphology 227:87-100

Sanyal J, Lu XX (2005) Remote sensing and GIS-based flood vulnerability assessment of human settlements: a case study of Gangetic West Bengal, India. Hydrol Process 19:3699-3716

Schumm SA (2007) Rivers and humans-unintended consequences. In: Gupta A (ed) Large rivers geomorphology and managaement. Wiley, Chichester, pp 517-550

Singh RL (1971) India: a regional geography. National Geographical Society of India, Varanasi

Singh IB (2004) Late quaternary history of the Ganga plain. J Geol Soc India 64:431-454

Singh LP, Prakash B, Singvi AK (1998) Evolution of the lower gangetic plain landforms and soils in West Bengal, India. Catena 33:75-104

Sinha R (1996) Channel avulsion and floodplain structure in the Gandak-Kosi interfan, north Bihar plains, India. Zeitschrift fur Geomorphol NF, Suppl.-Bd, 103, 249-268

Sinha R, Ghosh S (2012) Understanding dynamics of large rivers aided by satellite remote sensing: a case study from lower Ganga plains, India. Geocarto Int 27(3):207-219

Slingerland R, Smith ND (2004) River avulsions and their deposits. Annu Rev Earth Planet Sci 32:257-285

Tandon SK, Sinha R, Gibling MR, Dasgupta AS (2008) Late quaternary evolution of the Ganga Plains: myths and misconceptions, Recent developments and future directions. Gold Jubil Mem Geol Soc India 66:259-299

Vandenberghe J, de Moor JJ, Spanjaard G (2012) Natural change and human impact in a present-day fluvial catchment: the Geul River, Southern Netherlands. Geomorphology 159-160:1-14

Wadia DN (1975) Geology of India, 4th edn. Tata McGraw- Hill Publishing Company Limited, New Delhi

Williams GP, Wolman MG (1984) Downstream effects of dams on alluvial rivers. United States Govt. Printing Office, Washington

Xu K, Milliman JD, Yang Z, Xu H (2007) Climatic and Anthropogenic impacts on water and sediment discharges from the Yangtze River (Changjiang), 1950-2005. In: Gupta A (ed) Large Rivers: Geomorphology and Management. Wiley, Chichester, pp 609-626 